\title{
PARADIGMS OF EUROPEAN INTEGRATION PROCESSES IN THE EU, VISEGRÁD GROUP, AND UKRAINE
}

\author{
Svitlana Rostetska', Svetlana Naumkina²
}

\begin{abstract}
The scientific interest of the development of the theory and practice of cooperation of Central European countries of the Visegrád Group in the context of modern European integration processes is important for developing and implementing the strategy of foreign and domestic policy in European countries and Ukraine at the modern stage. At the beginning of the XXI century, under the changes in the geopolitical situation on the European continent, the countries of Central Europe (full members of the European Union) build a new operating system of international relations and accordingly continue to delegate some of their powers to suprastate institutions of the EU. The purpose of this scientific study is to determine paradigmatic aspects of European integration processes, modern threats arising in the EU, prospects for the interaction of EU countries, and to form a new format of cooperation of Ukraine and countries of the Visegrád Group. The aim of the creation of the alliance of the Visegrád Group (1991) was the desire to contribute to the construction of European security architecture and economic cooperation through the effective cooperation within European institutions. The whole activity of the Visegrád Group is aimed at strengthening stability in the Central European region. Risks in the economic sphere and strengthening of Euroscepticism are considered traditional for the EU functioning. In view of signing the Rome Declaration in 2017, the EU threats and challenges for the short-term (2018-2020) include: hybrid consequences of the aggression of the Russian Federation in Ukraine, European migrant crisis, a series of terrorist acts in European cities, unpredictable policy of the newly elected US president D. Trump in relation to the European security system, strengthening the position of far-left and far-right political forces in European states, Brexit and its consequences, in particular, risk of domino effect in other member countries of the Union. Therefore, we consider it appropriate to carry out system analysis of key relevant challenges and threats to the EU for 2018-2020 and to consider interconditionality and interdependence of problems that may affect the EU future. Given the defined trends, development and economic stability of each state are strategically important, however, special attention in this context should be paid to the analysis of the development of large countries of the European Union, such as Poland, Czech Republic, Slovakia, and Hungary. V4 countries are characterized by sustainable economic growth. If to analyse the Visegrád Four as a single national state, then the Visegrád Group is the fifth largest economy in Europe and the 12th in the world. The authors consider it too simplistic to define the essence of the Visegrád alliance only as a consolidation of the efforts of Central European countries for the sake of "returning to Europe" through Euro-Atlantic integration. In the modern dimension of events, the interaction format V4 + Ukraine is much more complex and more promising than it appears. Since joining NATO and the European Union in 1999 and 2004 by the Visegrád Group (i.e. Central European countries) geopolitically changes the status of the Central European Region, transforms bilateral and multilateral relations of Central European countries - full members of the EU with Ukraine. Moreover, this changes the system of relations within the Visegrád Four, as well as with other member states of the European Union.
\end{abstract}

Key words: Visegrád Group, European integration risks, modern threats of the EU, Brexit, migration, terrorism, Rome Declaration 2017, V4 development, Ukrainian cooperation.

JEL Classification: F60, O10, O57, R19

\footnotetext{
Corresponding author:

${ }^{1}$ South Ukrainian National Pedagogical University named after K. D. Ushynsky, Ukraine.

E-mail: svitlanarost@gmail.com

${ }^{2}$ South Ukrainian National Pedagogical University named after K. D. Ushynsky, Ukraine.

E-mail: svetlana.naumkina@gmail.com
} 


\section{Introduction}

The scientific interest of the development of the theory and practice of cooperation of Central European countries of the Visegrád Group in the context of modern European integration processes is important for developing and implementing the strategy of foreign and domestic policy in European countries and Ukraine at the modern stage. At the beginning of the XXI century, under the changes in the geopolitical situation on the European continent, the countries of Central Europe (full members of the European Union) build a new operating system of international relations and accordingly continue to delegate some of their powers to supra-state institutions of the EU.

The narrowing of the format of bilateral and multilateral relations of Central European countries the countries of the Visegrád alliance with the "outside world" - does not exclude Ukraine's active position in the Central European region.

The relevance of the issue of international relations of the Visegrád Group at the regional level is determined by the prospects and logic of the European integration development because an important component of their foreign policy should be the intensification of relations at a new level, the dynamic transformation of the regional system of international cooperation in the new geopolitical conditions on the European continent.

The purpose of this scientific study is to determine paradigmatic aspects of European integration processes, modern threats facing the EU, prospects for the interaction of EU countries, and to form a new format of cooperation of Ukraine and countries of the Visegrád Group.

\section{The methodology of research}

The key goal of the creation of the Visegrád alliance by the Central European countries as of 15 February 1991 (Visegrád - the Hungarian city, where it was founded) was to join efforts of three (at that moment) countries Poland, Hungary, and Czechoslovakia to exit the sphere of influence of the USSR, as a confrontation with possible attempts to restore the previous political regimes.

It is important to emphasize that the Visegrád alliance was not created as an alternative to European integration - and, please note, this is always emphasized by the leaders of at first three ones, and since 1993 already by official representatives of the four countries of the Visegrád block (Poland, Hungary, Czech Republic, and Slovakia).

More and more studies are devoted to the issues of development and interaction of countries of the Visegrád Four (V4), their analysis requires a special article, so we will consider the most important ones. Monograph "Visegrád: Possibilities and Constraints of Central European Cooperation" edited by Czech scholar Jiří Vykoukal is devoted to the consideration of evolutionary trends and historical retrospectives of the establishment and development of cooperation of V4 countries (Jiří Vykoukal, 2012), the author of the article Yeva Kish "Central Europe in the modern system of European regional integration" considers trends of development and harmonization of interests of European countries and conditions of modern realia (Kish, 2008). Therefore, in our research, there is a need to study Central European region from the viewpoint of the present time, to identify problems of interaction and ways to solve them, activation of the foreign policy of European countries and Ukraine in the EU region and Visegrád countries.

An important contribution in the study of the Visegrád Group is made by domestic and foreign scientists, such as S. I. Rostetska, S. L. Shvets, H. M. Perepelytsia, Ya. Turchyn, I. Mudriievska (Mudriievska, 2014) (relations of Ukraine and countries of the Visegrád Group in various sectors, for example, political, military, energy, humanitarian, and possibilities for cooperation V4 + Ukraine in the XX-XXI century). I. Artomov (Artomov, 2013) investigates the establishment of the Visegrád Group and the relationship of Ukraine and the Visegrád Group at the regional level. The article uses data from the official website of the Visegrád Group, MFA of Ukraine, and other official institutions.

The aim of the creation of the alliance of the Visegrád Group was and remains the desire to contribute to the construction of European security architecture and economic cooperation through the effective cooperation within European institutions. The whole activity of the Visegrád Group is aimed at strengthening stability in the Central European region (Vezel, Saakov, 2017).

Member countries are: Hungary (since 1991); Poland (since 1991); Slovakia (since 1993), and the Czech Republic (1993). All the countries of the Visegrád Group are countries with high-income level and very high human development index. Five key provisions clearly defined the purpose of the Visegrád alliance of Central European countries (Artomov, 2013): restoration of state independence, democracy, and freedom; the elimination of the remnants of the totalitarian regime in all spheres of life of society; the formation of parliamentary democracy and a modern state of law along with observance of fundamental human rights and freedoms; creation of a modern market economy; full integration into European political, economic, and legal systems in the format of safe development.

Recent geopolitical and geoeconomic events of the XXI century have completely transformed internal political situation in the European Union (EU) and in general in the Euro-Atlantic space. There are enough forecasts as regards to its further deterioration. Global, regional, and local trends of global development affect the functioning of the European Union in various ways. It has long been thought that the EU should act as a guarantor of stability on the European continent, but 
today, this integration structure is under the pressure of a number of systemic risks that destabilize the integration processes within the Union and hinder its sustainable development.

Risks in the economic sphere and strengthening of Euroscepticism are considered traditional for the EU functioning. Nevertheless, classic interpretations of threats to the EU functioning in the short- and middleterm are supplemented by migration problems, issues of hybrid influences, and other challenges that were not relevant a few years ago. Therefore, we consider it appropriate to carry out system analysis of key relevant challenges and threats to the EU for 2018-2020, namely, to consider interconditionality and interdependence of economic problems, security problems and threats (hybrid nature of modern conflicts and terrorism), institutional, social, and other internal and external problems that may affect the EU future.

And one of the insider ways to solve the defined problems, as the authors consider, is interaction and cooperation with Ukraine as a key integrator of pooling of economic, political, environmental, socio-cultural, and other interests.

Four levels of realization of European regional cooperation are distinguished (Artomov, 2013):

- international level: realization of the policy of panEuropean interests, coordination of national regional policies to participate in the balanced development of the European space;

- state level: development of a national policy for the development of European regional cooperation and harmonization of national interests with pan-European ones, as well as the harmonization of national and regional goals;

- regional level: implementation of European regional cooperation policy taking into account interests of the state and local authorities, coordination among the regions of neighbouring countries;

- local level: coordination of development plans of local authorities with considerable attention to regional and national interests, particular cooperation between subjects of border areas.

Cooperation between various countries and Ukraine has evolved both bilaterally and in the Visegrád Four format. However, in some areas, cooperation with the countries of the Visegrád Group resumed in 1998, after the accession of the V4 countries to the European Union. It is known that European regional level of integration is based on the commonality of the territorial boundaries of the integrating states, on the same historical development paths and is supplemented by the natural, economic, transport and communication, scientific and technical potential, the commonality of economic problems, foreign political and geopolitical interests. Taking into account the practice of cooperation of the Visegrád Four in Ukraine, European regional cooperation is intensifying in many directions.
Application of the practice of interaction of partner countries within the Visegrád strategy of mechanisms and forms of cooperation will allow optimally forming integration strategy of Ukraine and searching for additional levers that could affect the deepening of relations between the state and the European Union and our closest states.

\section{Results and discussion}

Famous events of the last decade of the XXI century have significantly aggravated, in particular, changes in the internal political situation in the European Union (EU) and in the Euro-Atlantic space; there are many forecasts about their further deterioration. Global, regional, and local trends of global development affect the functioning of the European Union in various ways. Despite the fact that basic functions of the EU are to act as a guarantor of stability on the European continent, today, this integration structure is under the pressure of a number of system risks that destabilize the integration processes within the Union and hinder its sustainable development.

By systematizing key threats and challenges to the EU functioning, it is necessary to distinguish between their internal and external nature and their interdependence.

Mostly internal problem of the EU should include the institutional crisis (Brexit problem and the formation of a new future for the EU); economic challenges, which are partly caused by external factors (Dorosh, Ivasechko, 2017).

Key external threats include strengthening of the challenges and threats, in the form of the newest hybrid conflicts in the region, the migration crisis, the coming to power of D. Trump in the USA, terrorism as a way to destabilize the internal situation in the EU member states.

Therefore, traditional economic challenges within the internal development of the European Union for 2018-2020 remain relevant but not so critical as compared to the newest threats and social challenges. According to the results of 2017, analysts record a certain improvement in the economic situation and minimal positive dynamics of key macroeconomic indicators in most EU member states. Meanwhile, a number of system economic problems caused by unaddressed consequences of the global economic crisis, the slow pace of economic growth in the post-crisis period, the presence of considerable budget deficits and debt obligations in some countries, high unemployment, etc., remain unsolved (Dorosh, Ivasechko, 2017).

The internal institutional crisis of the EU and the exit of Great Britain from the EU (Brexit) have become traditional over the last few years. In our view, the European Union is experiencing a critical period of its history and, during the period of 2017-2018, this challenge will greatly affect future integration 
processes. Undoubtedly, Brexit has become a shock to the European Union and the West as a whole, the consequences of which are extremely difficult to predict: if some experts believe that it will be the beginning of the end of the EU, then the others see it as an important step for unification: Europe will have to consolidate to preserve unity. Therefore, it is obvious that the exit of Great Britain from the EU will have both traditional consequences and those that are difficult to predict today (G20: Brexit, 2016).

Despite the fact that Brexit is usually considered as a negative phenomenon, any crisis is a chance for EU development. For example, the EU will be able to revise past agreements concluded based on the "special position" of Great Britain, making them more profitable for the continental states of Europe. It is also clear that the exit of Great Britain from the EU and further consolidation of other members of the Union will suspend the admission of new members.

Problems of Brexit and separatist mood are determined by the spread of efferent trends in EU development. It is about the desire to weaken the efferent trends within the EU, that is, to pause/stop the transformation of the EU into a "supra-state" with centralized management, and to put in force a peculiar "EU-light", where member states would receive back a significant share of their state prerogatives that they delegate Brussels at the entrance. This is favoured by the Netherlands, Italy, Belgium, and the Visegrád countries (Poland, Czech Republic, Slovakia, and Hungary). However, the pre-accession countries (Serbia, Moldova, and Ukraine) do not lose their desire to join the EU and support the necessary conditions.

Therefore, relevant internal challenges in 20182020 should include the threat of domino effect and strengthening of the EU exit trends by other states. The event of Brexit may provoke a chain reaction, as the Union without Great Britain becomes less attractive to liberal wealthy northern states such as Denmark and the Netherlands, where the demands for a similar referendum can increasingly be heard. An exit from the EU makes sense if the state is guaranteed more effective economic development. However, if the British example will show the opposite, then the number of those who want to separate will sharply decrease (G20: Brexit, 2016).

In the organizational and economic, and also institutional sphere, a general internal threat to the EU functioning is the inability of member states to conduct a coordinated common internal and external policy (the split reaction to the hybrid policy of Russia is a vivid example).

When considering key foreign challenges, one should note that the hybrid war of the Russian Federation towards Ukraine and the annexation of Ukrainian territories occupy the priority positions for EU and Member State leaders. Researchers predict that in the near future, the EU states will devise the following variants of development of interactions of security threats in the context of this problem (G20: Brexit, 2016; Dorosh, Ivasechko, 2017):

- the threat of the Russian Federation will force most EU Member States to continue to increase defence financing after the years of spending cuts;

- the EU will intensify variants of diversification of energy supply sources in order to get rid of dependence on Russian gas and generally reduce economic dependence on Russia;

- EU sanctions against the Russian Federation will continue, despite the fact that they negatively affect not only Russia but also on the unstable economy of Western European states.

Analysts assert that for the European Union, such a state of relations with the Russian Federation was not a surprise, and the understanding that Putin carries out his own strategy in Europe has become inevitable (Gogan, 2017; Kermach, 2015). The validity of EU sanctions against Russia will continue until summer 2019. Countries such as Hungary, Italy, and Austria are hoping to resume economic cooperation with Russia, seek to lift these restrictive measures. However, prolonged hostilities in the Donbas during 20142018 show that the RF and separatist forces in the East of Ukraine will continue not to comply with the Minsk accords. So, the reasonableness and compliance with commitments by the EU in relation to aggression in Ukraine and policy towards Russia in general will become one of the strength tests for the unity of Europe (Vezel, Saakov, 2017; Frolov, 2018).

Another one urgent external threat that will not lose its significance in 2018-2020 is a continuous influx of migrants to Europe due to problems in North Africa and the Middle East and Ukraine. During 2015, as a result of the war in Syria, 1,3 million migrants have requested asylum in the $\mathrm{EU}$, which significantly exceeds the figures of previous years. European migrant crisis started in 2015 is interpreted today as "humanitarian catastrophe" caused by a massive flow of migrants from Africa and the Middle East, who left their homes with a hope for a peaceful life and comparable prosperity in the EU states. It is clear that a lot of EU Member States were not prepared for a major migrant crisis and, as a result, felt the negative effects of this process on such important systems of social response to emergencies as housing, education, and healthcare. As a consequence of the uncontrolled flow of refugees, states are forced to direct the financial and program priorities of social integration for the temporary custody of migrants with the possible reduction of social guarantees for citizens of the European presidency (Yevropejska bezpeka, 2016).

The additional costs for meeting the social needs of refugees, as it was demanded in Germany and Austria, can lead to a significant "political backlash" or even a tough reaction, as happened between local politicians 
in Cologne. At the same time, migration flows contribute to the rapid growth of European civil society activities to meet the basic needs of refugees, such as clothing or first aid and thus opens up new horizons to ensure European prosperity (Gogan, 2017).

The migration crisis undoubtedly affects the internal functioning of the EU. So, it first questioned the unity of European countries and the validity of the Schengen agreements, one of the main priorities of European integration, which ensures freedom of movement within the EU, especially for those countries that have become part of the transit route of migrants from the Middle East. In addition, there is a lack of unity in the issue of immigrants' rights to claim social benefits in EU states.

Already today in the EU, there is a practice of restoration of control at internal borders over the danger of a migration crisis. The relevant right is enshrined in Art. 23 of the Schengen Borders Code. Germany restored control on the land border with Austria for the period from February 11 to May 11, 2017; Austria - with Slovenia and Hungary; Denmark will check sea ports with ferry connections to Germany and the boundaries of land borders. France, in turn, has restored control at all internal borders for a period from February 27 to July 15,2017 , due to a constant terrorist threat (Yevropejska bezpeka, 2016; Pit Dzh., 2017).

Along with the migrant crisis, terrorism remains the key destabilizing external factor for the EU. A potential danger to EU Member States, in particular, such leading ones as France and Germany, whose migration policy is extremely imperfect and overfull by double standards, is a great number of Muslim migrant among their populations who can become an instrument for implementing extremist plans in Europe (Solodko, Fitisova, 2016; Dorosh, Ivasechko, 2017).

The terrorist attacks in Paris in November 2015 and in 2017, in Brussels - in March 2016, in Istanbul - in June 2016 and in 2018, in Nice - in July 2016 highlighted the scale of the threat of the spread of terrorism, in particular, through the activities of branched Islamist networks in Western countries, formed over the past decades. They demonstrated that terrorist attacks on unprotected places of mass concentration of people and infrastructural facilities turn into a permanent factor of European reality and influence decision-making within the EU (Yevropejska bezpeka, 2016; Knipp, 2016).

A lot of foreign experts explain this by the inefficiency of the EU security policy, which is caused by a number of factors. Among the key ones, the following can be distinguished: the excessive self-esteem of the intelligence services of some EU member states in relation to the ability to provide national security on its own; too high levels of democracy and liberalism in the states; unprofessionalism and failure of the special services of certain states and special services of the European Union to resist terrorist activity in Europe; ignoring the causes and consequences of previous terrorist acts in European cities and the lack of strategic cooperation with the special services of other European states in the context of the fight against terrorism, etc. (Dorosh, Ivasechko, 2017; Gogan, 2017; Yevropejska bezpeka, 2016; Pit Dzh., 2017).

For a real fight against terrorism at the internal level, it is necessary to intensify the potential of national security and to review the EU counter-terrorism policy (Vonsovych, 2016).

A key challenge to the EU in the near future is the new format of relations between the USA and the Russian Federation. As a result, NATO and EU defence officials warn the newly elected US President, D. Trump, about improving relations with Russian President Vladimir Putin. It is about the fact that the EU calls the USA to remain an outpost of European security, especially in the context of defence against Russia's hybrid challenges. Therefore, the further development of the European security system and the placement of forces in the international arena depend on the position of $\mathrm{D}$. Trump.

In order to solve urgent problems and both internal and external threats, as well as for the purpose of their possible prevention, the leaders of European countries in March 2017 (on the eve of the exit of Great Britain from the Union) adopted the Rome Declaration, which identified key areas of work for the next decade (Rymska deklaraciya EU, 2017). They include: economic development, security and leadership in the world arena. The declaration signed by leaders of 27 countries (without Great Britain), leaders of the European Parliament, European Commission, and European Council, includes four key items, which will be given attention in the coming years and which are answers to current challenges in the near future.

A safe and secure Europe. The Declaration defines priorities of security of all citizens, in the fight against terrorism and organized crime; free movement within secure external borders. Emphasizes the need to develop and implement an efficient, responsible, and sustainable migration policy while respecting international norms and rules.

A prosperous and sustainable Europe. It is about the EU development that guarantees economic growth, competition and innovation, where the common market operates efficiently, conditions are created for investment and job creation, priority is given to technological transformations, structural reforms, and especially to the security and availability of energy, a clean and safe environment.

A social Europe. In the EU, priorities are determined as economic and social progress taking into account the diversity of national systems and the key role of social partners, trade unions, ensuring equality between women and men, as well as rights and equal opportunities for all, in particular, in the field of education.

A stronger Europe on the global scene. The Declaration proclaims that decisive are the further 
developing existing partnerships and building new ones; strengthening its common security and defence, in particular, in cooperation and complementarity with NATO and the UN; especially on the values and protection of human rights, promoting free and fair trade and a positive global climate policy (Rymska deklaraciya EU, 2017).

Given the defined trends, development and economic stability of each state are strategically important, however, special attention in this context should be paid to the analysis of the development of large countries of the European Union, such as Poland, Czech Republic, Slovakia, and Hungary. V4 countries are characterized by sustainable economic growth (Hotova, 2012). If to analyse the Visegrád Four as a single national state, then the Visegrád Group is the fifth largest economy in Europe and the 12th in the world (Dorosh, Ivasechko, 2017).

Analysing GDP per capita indicators for 2017, we see that the highest indicator is determined in the Czech Republic, followed by Slovakia and Poland (Table 1) (Palinchak, Prykhodko, Steblak, Savka, 2017). The average GDP in 2016 for the whole group was 25797 USD.

Poland has the largest economy in the region (GDP (PPP) totalling 1004,5 billion USD, takes 23rd place in the world). According to the data of the United Nations and the World Bank, this is a high-income economy ("V4", 2014; Palinchak, Prykhodko, Steblak, Savka, 2017), with a high quality of life, and very high living standards. The Polish economy is the sixth largest in the EU and one of the fastest growing European economies (Paweł Dziekański, 2017).

The main industries are mining, machine building (cars, buses, accessories), metallurgy, chemical, electrotechnical, textile, and food industries. High technology and the IT sector are also growing due to investors such as Google, Toshiba, Dell, GE, LG, and Sharp.

The economy of the Czech Republic is the second largest (GDP (PPP) is generally fifth in the world) in the group. Today, the Czech Republic is an industrialized country and, according to the World Bank, one of the thirty most developed countries in the world. The main problem it faces is the inequality between the regions ("V4", 2014; Palinchak, Prykhodko, Steblak, Savka, 2017).
The main branches of industry in the Czech Republic are chemicals, machinery, food industry, and metallurgy. Other important industries - energy, construction. Industry accounts for $35 \%$ of the Czech economy. The Czech Republic produces the largest number of cars per capita. Major manufacturers are Skoda Auto, Peugeot-Citroen, Toyota, i Hyundai. Other large companies - CEZ Skoda, Panasonic, Tatra, Arcelor Mittal, PPF, Pilsner Urquell, Aero, and many others.

Hungary has the third-largest economy in the group (the total GDP - 255,254 billion dollars, 57th place in the world). The main branches of industry are machine building, (cars, buses), chemical, electrotechnical, textile, and food industries ("V4", 2014; Palinchak, Prykhodko, Steblak, Savka, 2017).

The service sector accounts for a large part of the budget, and its role in the Hungarian economy is steadily increasing. Hungary is located in the heart of Central Europe; its strategic position plays a significant role in the growth of the service sector. The central position of the country makes it suitable for investment.

Slovakia has a rather powerful economy (GDP is 158,428 billion USD, 70th place in the world) (Palinchak, Prykhodko, Steblak, Savka, 2017). Today, Slovakia is an advanced industrial state. The automotive industry is of vital importance to the economy of Slovakia. Major car companies such as Volkswagen, PSA Peugeot-Citroen, KIA (and since 2018 - Jaguar-Land Rover) have assembly lines in the country. According to the results of 2016, Slovakia ranks 13th in terms of bilateral trade in goods between Ukraine and European countries with a share of $2.8 \%$ of the total (Visegrád Group, 2018).

Ukraine occupies one of the prominent places in the cooperation of the Visegrád Group with the Eastern European partners (Martynyuk, 2015). Cooperation is held annually in various forms, such as intergovernmental contacts, various events in the format V4 + Ukraine in the political, legal, military, energy, socio-cultural, managerial, and regional spheres. An analysis of the genesis of relations in each of these spheres will make it possible to determine the effectiveness of this cooperation.

Poland, the Czech Republic, Slovakia, and Hungary have close relations and actively cooperate in the economic sphere with Ukraine. The activity

Table 1

Dynamics of GDP per capita in the countries of the Visegrád Group

\begin{tabular}{|l|l|c|c|c|c|}
\hline \multicolumn{1}{|c|}{ Country } & \multicolumn{1}{|c|}{ Indicator } & 2014 & 2015 & 2016 & 2017 \\
\hline Czech Republic & Purchasing Power Parity GDP per capita** & 27200,051 & 28086,483 & 29115,997 & 30261,345 \\
\hline Hungary & Purchasing Power Parity GDP per capita & 20065,084 & 20817,433 & 21597,298 & 22422,366 \\
\hline Poland & Purchasing Power Parity GDP per capita & 21214,302 & 22201,121 & 23339,843 & 24581,780 \\
\hline Slovakia & Purchasing Power Parity GDP per capita & 24605,348 & 25524,656 & 26710,975 & 28137,028 \\
\hline
\end{tabular}

Source: Formed by the author based on (World Economic Outlook Database, April 2017)

** Czech Republic: Gross domestic product based on purchasing-power-parity (PPP) per capita GDP (Current international dollar)

*** Developed based on data of the International Monetary Fund (State Statistic Service; Visegrád Group) 
of V4 covered all areas of cooperation - security, political, economic, socio-cultural, and so on. According to the declaration adopted on May 12, 2004, cooperation in the framework of V4 was foreseen in 41 directions. Poland's cooperation with Ukraine is at a high-quality level.

As of 31 December 2016, the volume of Polish investments in Ukraine amounted to 785,9 million USD, which is $1.8 \%$ of the total volume of foreign investment in Ukraine. Since the beginning of 2016, Polish investments have shrunk by 45,3 million USD. The most important Polish investments in Ukraine are the building ceramics factory "Cersanit", parquet factory "Barlinek", furniture factory "Nowy Styl", packing factory "Can-Pack" and others ("V4", 2014; Visegrád Group, 2018).

The dynamics of the share of the countries of the Visegrád Group in the foreign goods trade of Ukraine is given in Table 2 (Petrova, Malyuta, Berezhnyuk, 2018).

Table 2 shows that Poland is the undisputed leader in exports and imports because an average share in exports is $14.76 \%$ and imports - $14.44 \%$. Peak shares in the foreign trade of Ukraine with Poland are observed in 2012, 2014, and 2016 in exports and in 2012 and 2016 in imports. The largest share in both export and import of Poland was recorded in 2016, which is explained by the implementation of the Free Trade Agreement with the EU.

Hungary has a significant share in the exports and imports of Ukraine because the share of exports to Hungary is $7.89 \%$, Hungary's imports to Ukraine $5.44 \%$. Peaks in exports were observed in 2013, and in imports - in 2015. After the reduction of the share in 2013, Ukrainian exports to Hungary started to increase only in 2016. However, whether it is a certain tendency or only an accidental growth can be determined only after an analysis of the share of Ukraine's exports to Hungary in the next years. Slovakia and the Czech Republic have almost the same share in foreign trade with Ukraine. The share of exports of these countries is almost the same. The Czech Republic, in comparison with Slovakia, has a bigger share in imports, despite the fact that Ukraine and the Czech Republic do not have common borders and Euroregions.

The analysis of the commodity structure of imports from the Visegrád Group countries to Ukraine indicates that the structure of imports of the Visegrád countries is more rational than the structure of Ukraine's exports to these countries. In the import of the Visegrád countries in Ukraine, there are many products with a large share of value added and investment goods, namely, electric cars are present in the import of Poland (an average of $8.87 \%$ ), Hungary (an average of $20.84 \%$ ), the Czech Republic (an average of $13.11 \%$ ); nuclear boilers are present in the import of Poland (an average of 7.83\%), the Czech Republic (an average of $13.11 \%)$, nuclear reactors are in Hungary's imports (an average of 6.70\%); land transport means are in the import of Poland (an average of 3.52\%), Slovakia (an average of $21.25 \%$ ), the Czech Republic (an average of $13.11 \%$ ) (Petrova, Malyuta, Berezhnyuk, 2018).

The Visegrád Four, like Ukraine, attaches great importance to the development of regional and cross-border cooperation. It is extremely profitable economically because it is primarily about the need to establish a proper border infrastructure (including technical modernization of crossing points on the Ukrainian border with Poland, Slovakia, and Hungary), the development of beneficial economic cooperation between the border regions of Ukraine and neighbouring countries, and the labour movement. It is also necessary to intensify joint actions at the regional level in order to solve environmental problems, problems of employment, etc. (Frolov, 2018).

\section{Conclusions}

As a result of radical socio-political transformations at the end of the XX century, at the beginning of the XXI, in the Central European countries, there has been a radical change in the domestic political system and

Table 2

Dynamics of the share of the countries of the Visegrád Group in the foreign goods trade of Ukraine

\begin{tabular}{|c|c|c|c|c|c|c|c|c|c|}
\hline Country & 2008 & 2009 & 2010 & 2011 & 2012 & 2013 & 2014 & 2015 & 2016 \\
\hline \multicolumn{10}{|l|}{ Export, \% } \\
\hline Poland & 12,89 & 12,71 & 13,69 & 15,54 & 15,81 & 15,20 & 15,55 & 15,19 & 16,30 \\
\hline Slovakia & 5,02 & 4,53 & 4,35 & 4,68 & 3,93 & 4,49 & 3,94 & 3,59 & 3,49 \\
\hline Hungary & 7,54 & 7,68 & 6,58 & 7,46 & 8,84 & 9,29 & 8,88 & 6,98 & 7,80 \\
\hline Czech Republic & 3,10 & 3,58 & 4,79 & 4,68 & 4,13 & 4,91 & 4,54 & 4,15 & 4,15 \\
\hline \multicolumn{10}{|l|}{ Import, \% } \\
\hline Poland & 14,82 & 14,09 & 14,60 & 12,36 & 13,63 & 15,06 & 14,57 & 15,15 & 15,71 \\
\hline Slovakia & 2,57 & 1,98 & 2,31 & 2,34 & 2,24 & 2,45 & 2,02 & 2,25 & 2,53 \\
\hline Hungary & 4,44 & 4,40 & 6,35 & 2,15 & 4,43 & 5,17 & 6,94 & 10,49 & 4,67 \\
\hline Czech Republic & 4,76 & 4,04 & 3,91 & 4,58 & 4,76 & 3,69 & 3,26 & 3,12 & 3,82 \\
\hline
\end{tabular}

Source: compiled by the authors based on (data of the International Monetary Fund and State Statistic Service of Ukraine (State Statistic Service; Visegrád Group)) 
the foreign policy of the countries and the basic radical transformation of the system of international relations at both the global and regional levels.

Firstly, as a result of the collapse of the bipolar system of international relations, the status of the Central European region and each of the Central European countries has changed significantly.

Secondly, all the countries of Central Europe were at the beginning of the period of systemic socioeconomic transformations, the priority in this context was given to foreign-economic relations aimed at the West. Foreign-policy security priorities were somewhat different in different countries. However, during 2000-2017, the Euro-Atlantic dimension has become a major direction for the development and strengthening of the European security system in the region.

Thirdly, the Central European countries consider the "overcoming" of the geopolitical vacuum in the Central European region on the basis of general instability as an accession to powerful international and regional economic and security structures, in particular, the Euro-Atlantic course and the accession to the European Union were identified as a priority for the Visegrád Group. The strategy of the foreign policy of Poland, Hungary, and the Czech Republic was clearly directed, focused on the "West". That is, the formation of the Visegrád alliance itself did not serve as an alternative to their earliest entry into the EU and NATO.

Nevertheless, we consider it too simplistic to define the essence of the Visegrád alliance only as a consolidation of the efforts of Central European countries in order to "return to Europe" through EuroAtlantic integration.

In the modern dimension of events, the interaction format V4 + Ukraine is much more complex and more promising than it appears. Since joining NATO and the European Union in 1999 and 2004 by the Visegrád Group (and they, on our deep conviction, are the countries of Central Europe) actually geopolitically changes the status of the Central European Region, transforms bilateral and multilateral relations of Central European countries - full EU members with Ukraine. Moreover, this changes the system of relations within the Visegrád Four, as well as with other member states of the European Union.

Therefore, a number of internal and external threats facing the European Union today (including the Russian Federation's aggression in Ukraine, European migrant crisis, a series of terrorist acts in European cities, D. Trump's unpredictable policy in relation to the European security system, strengthening the position of far-left and far-right political forces in European states, Brexit and its consequences, in particular, risk of domino effect in other member countries of the Union) induced the leaders of European countries to be more consolidated in terms of a common vision of the future of the European Union and, consequently, to incur obligations as regards to promising directions for the EU development. The Rome Declaration of 2017 may become a document, the implementation of which will not only become a strategic basis for the formation of an adequate response to the urgent internal challenges of the EU development but will also strengthen the position of the unification of countries in the international arena, consolidate the states of Europe in the fight against external threats.

Therefore, research on the development of the interaction of European countries with Ukraine for combating internal and external threats and the consolidation positions of political elites and public opinion in the EU member states regarding the future of this integration structure should be considered promising.

The foreign trade of Ukraine with the countries of the Visegrád Group is extremely uneven. So, the main partners are Poland and Hungary. In terms of trade security indicators, trade with Slovakia is most promising.

The commodity structure of Ukrainian trade with the Visegrád countries is highly irrational. The main exports items are commodities of the raw material group. Ukraine is energy dependent on these countries. At the same time, Ukraine's exports to Hungary include a significant share of innovative goods. Nevertheless, in our opinion, the cooperation of the Visegrád Group with Ukraine is beneficial.

Firstly, it is an increase in sales markets, the number of consumers of products and services; secondly, it is the expansion of business ties, and thirdly, cheap labour, skilled workers, cooperation in the field of tourism, investment in certain profitable areas, and so on. For Ukraine, such cooperation can also be defined by a number of advantages. Firstly, it is new investments and financial flows in various sectors, secondly, multilateral tourism development, and thirdly, the development of enterprises in the region because, through small national markets, the surrounding business environment can be modernized in such a way as to stimulate the development of local enterprises and attract foreign investors. Despite the creation of the internal market, there are still many practical difficulties for trade in goods and services, and there are also formal barriers that hinder cooperation. But the joint activities of the Visegrád Group and Ukraine can bring great benefits to both the V4 countries and Ukraine in various spheres. Also, extremely important is the Visegrád Group's assistance to Ukraine, its representation as a democratic country in the arena of international relations, help in conducting reforms, and support in the aspiration to join the European Union. 


\section{References:}

Artyomova, I. V., Vashchuk, O. M., Rudenko, O. M. (2013). Modeli i mekhanizmy rehulyuvannya yevrorehionalnoho spivrobitnytstva Ukrayiny: Monohrafiya [Models and mechanisms of regulation of Euroregional cooperation of Ukraine: Monograph]. Uzhhorod: MI III «Hrazhda».

Dorosh, L., Ivasechko, O. (2017). Osoblyvosti funktsionuvannya ta vyklyky rozvytku YES u blyzkiy perspektyvi (2017-2018 rr.) [Features of functioning and challenges of EU development in the near future (2017-2018)]. Politychni nauky. Retrieved from: http://science.lpnu.ua/uk/shv/vsi-vypusky/tom-3-chyslo-1-2017/osoblyvostifunkcionuvannya-ta-vyklyky-rozvytku-yes-u-blyzkiy

Frolov, S. M. (2018). Doslidzhennya problem orhanizatsiyi i realizatsiyi byudzhetnoho protsesu v Ukrayini [Research on the organization and implementation of the budget process in Ukraine]. Retrieved from: http://essuir.sumdu.edu.ua/bitstream/123456789/8043/3/a.r.9.pdf

Gogan, E. (2017). More lyxa. Svit u 2017.

G20: Brexit (2016). G20: Brexit posylyuye globalni ekonomichni ryzyky Retrieved from: http://ua.112.ua/svit/ g20-brexit-posyliuie-hlobalni-ekonomichni-ryzyky-327162.htm

Hotova, E. (2012). Visegrád Group: experience and prospective. Problemi nasionalanoi straterii, 4(12), 50-70.

Kermach, R. (2015). Problema bizhenciv v YeS: dovgostrokovi naslidky novogo vyklyku. Fond "Demokratychni iniciatyvy" imeni Ilka Kucheriva. Retrieved from: http://dif.org.ua/article/problema-bizhentsiv-v-esdovgostrokovi-naslidki-novogo-vikliku

Kish, Ye. B. (2008). Tsentralna Yevropa v suchasniy systemi yevrorehionalnoyi intehratsiyi: monografiya [Central Europe in the modern system of Euroregional Integration: monograph]. Uzhhorod: Lira.

Knipp, K. (2016). Potencijni islamisty-terorysty - spravzhnij vyklyk dlya pravovoyi derzhavy Deutsche Welle. Retrieved from: http://www.dw.com/uk

Martynyuk, O. A. (2015). Formuvannya imperatyviv staloho rozvytku dlya strukturnykh peretvoren ekonomiky [Formation of the imperatives of sustainable development for structural transformations of the economy]. Visnyk Odeskoho natsionalnoho universytetu. Seriya: Ekonomika, 20(6), 44-48.

Mitryayeva, S. I., Lendel, M. O., Stryapko, A. D., Kryzhevskyy, A. M. (2014). Spivrobitnytstvo z krayinamy Vyshehradskoyi Chetvirky yak instrument yevropeyskoyi intehratsiyi ta modernizatsiyi Ukrayiny: analit. dop. [Cooperation with the Visegrád Four countries as an instrument of European integration and modernization of Ukraine: analyst]. Kyiv: NISS.

Mudriievska, I. (2014). Cooperation Ukraine and Vishegrad grope state in form V4+1 at the end XX - at thebiging XXI. Chasopis ukrainskoj ictorii, 29, 85-90.

Palinchak, M. M., Prykhodko, V. P., Steblak, D. M., Savka, V. Ya. (2017). Spivrobitnytstvo Vyshehradskoyi hrupy ta Ukrayiny [Cooperation of the Visegrád Group and Ukraine]. Naukovyy Visnyk Uzhhorodskoho natsionalnoho universytetu. Seriya: Mizhnarodni ekonomichni vidnosyny ta svitove hospodarstvo, 13-2, 72-77.

Paweł Dziekański (2017). Economic effectiveness of the activities of local self-government units in the light of the municipality financial resources. Naukovyy visnyk Polissya, 3(11). doi: 10.25140/2410-9576-2017-1-3(11)-76-82

Petrova, H. Ye., Malyuta, I. A., Berezhnyuk, I. H. (2018). Suchasna torhivlya tovaramy Ukrayiny ta krayin Vyshehradskoyi hrupy yak vektor yevrointehratsiyi [Contemporary trade in goods of Ukraine and the Visegrád countries as a vector of European integration]. Pryazovskyy ekonomichnyy visnyk, 4(09), 10-15.

Pit Dzh. (2017). Barometr Brexit. Svit u 2017 roci.

Rymska deklaraciya EU (2017). Rymska deklaraciya YeS: chotyry priorytety rozvytku Yevrosoyuzu. Retrieved from: http://www.eurointegration.com.ua/news/2017/03/25/7063585/

Solodko, A., Fitisova, A. (2016). Migracijna kryza v YeS: statystyka ta analiz polityky. Analitychnyj centr CEDOS. Retrieved from: http://www.cedos.org.ua/uk/migration/mihratsiina-kryza-v-yes-statystyka-ta-analiz-polityky

State Statistic Service. Official web-site. Retrieved from: http://www.govstat.ua

«V4» (2014). «V4» International Monetary Fund. Retrieved 17 June 2014. Retrieved from: http://www.imf.org/ external $/ \mathrm{pubs} / \mathrm{ft} /$ weo $/ 2014 / 01 /$ weodata/weorept.aspx?prx $=48 \& \mathrm{pr}$. $8 \& \mathrm{sy}=2013 \& \mathrm{ey}=2019 \& \mathrm{scsm}=1 \& \mathrm{ssd}=$ $1 \&$ sort $=$ country\&ds=.\&br=1\&c=964\%2C935\%2C936\%2C944\&s=PPPPC\&grp=0\&a=\#cs 1

Visegrád Group. Official web-site. Retrieved from: http://www.visegradgroup.eu

Vezel, B., Saakov, V. (2017). Samit YeS - najvazhlyvishi temy zustrichi na Malti. Deutsche Welle. Retrieved from: http://www.dw.com/uk/\%D

Vonsovych, O. S. (2016). Prezydentski vybory u SShA: naslidky dlya mizhnarodnoyi ta yevropejskoyi bezpeky. Retrieved from: http://grani.org.ua/index.php/journal/article/download/837/845

Yevropejska bezpeka (2016). Yevropejska bezpeka pid tyskom gibrydnykh zagroz. Analitychna dopovid do Shhorichnogo Poslannya Prezydenta Ukrayiny do Verkhovnoyi Rady Ukrayiny "Pro vnutrishnye ta zovnishnye stanovyshhe Ukrayiny v 2016 r.”. Kyiv: NISD. Retrieved from: http://www.niss.gov.ua/content/articles/files/ poslanya_new-cc2e3.pdf 